\title{
Paenibacillus taiwanensis sp. nov., isolated from soil in Taiwan
}

\author{
Fwu-Ling Lee, ${ }^{1}$ Hsiao-Ping Kuo, ${ }^{1}$ Chun-Ju Tai, ${ }^{1}$ Akira Yokota ${ }^{2}$ \\ and Chi-Chu Lo ${ }^{3}$
}

Correspondence

Chun-Ju Tai

tcj@firdi.org.tw

\author{
${ }^{1}$ Bioresource Collection and Research Center, Food Industry Research and Development \\ Institute, PO Box 246, Hsinchu 30099, Taiwan \\ ${ }^{2}$ Institute of Molecular and Cellular Biosciences, The University of Tokyo, Yayoi 1-1-1, \\ Bunkyo-Ku, Tokyo 113-0032, Japan \\ ${ }^{3}$ Division of Bio-Pesticide, Taiwan Agricultural Chemicals and Toxic Substances Research \\ Institute, Council of Agriculture, Wufong, Taichung 41358, Taiwan
}

\begin{abstract}
Among a large collection of Taiwanese soil isolates, a novel Gram-variable, rod-shaped, motile and endospore-forming bacterial strain, designated G-soil-2-3 ${ }^{\top}$, was isolated from farmland soil in Wu-Feng, Taiwan. The isolate was subjected to a polyphasic study including 16S rRNA gene sequence analysis, DNA-DNA hybridization experiments, fatty acid analysis and comparative phenotypic characterization. 16S rRNA gene sequence analysis indicated that the organism belongs within the genus Paenibacillus. It contained menaquinone MK-7 as the predominant isoprenoid quinone and anteiso- $\mathrm{C}_{15: 0}(40.5 \%)$, iso- $\mathrm{C}_{15: 0}(13.1 \%)$, iso- $\mathrm{C}_{16: 0}(10.8 \%)$ and anteiso- $\mathrm{C}_{17: 0}(7.3 \%)$ as the major fatty acids. Phylogenetically, the closest relatives of strain G-soil-2-3 ${ }^{\top}$ were the type strains of Paenibacillus assamensis, Paenibacillus alvei and Paenibacillus apiarius, with 16S rRNA gene sequence similarity of 95.7, 95 and $95.2 \%$, respectively. DNA-DNA hybridization experiments showed levels of relatedness of $2.8-9.0 \%$ of strain G-soil-2-3 ${ }^{\top}$ with these strains. The $G+C$ content of the DNA was $44.6 \mathrm{~mol} \%$. Strain G-soil-2-3 ${ }^{\top}$ was clearly distinguishable from $P$. assamensis, $P$. alvei and $P$. apiarius and thus represents a novel species of the genus Paenibacillus, for which the name Paenibacillus taiwanensis sp. nov. is proposed. The type strain is G-soil-2-3 ${ }^{\top}\left(=\mathrm{BCRC} 17411^{\top}=\mathrm{IAM}\right.$ $15414^{\top}=$ LMG $23799^{\top}=$ DSM $18679^{\top}$ ).
\end{abstract}

In a comparative analysis of $16 \mathrm{~S}$ RNA gene sequences of 51 species of the genus Bacillus, Ash et al. (1991) described five principal groups of strains, of which rRNA group 3 and group 4 bacilli of Ash, Farrow, Wallbanks and Collins have since been afforded generic status as Paenibacillus (Ash et al., 1993) and Brevibacillus (Shida et al., 1996), respectively. The genus Paenibacillus was considered to be a member of the family 'Paenibacillaceae', proposed to group several bacterial taxa previously attributed to the genus Bacillus (Garrity \& Holt, 2001). At the time of writing, the genus Paenibacillus comprised more than 70 recognized species, with Paenibacillus polymyxa as the type species. The description of the genus was emended by Shida et al. (1997a, b).

In the present study, the taxonomic position of a Taiwanese soil isolate, designated strain G-soil-2- $3^{\mathrm{T}}$, was studied by using a polyphasic approach. Based on levels of $16 \mathrm{~S}$ rRNA gene sequence similarity, DNA-DNA relatedness values,

The GenBank/EMBL/DDBJ accession number for the 16S rRNA gene sequence of strain G-soil-2-3' $\left(=\right.$ BCRC $\left.17411^{\top}\right)$ is D0890521. fatty acid composition, phenotypic characterization and the generally accepted standards for describing novel species (Kämpfer et al., 2003; Stackebrandt \& Goebel, 1994; Vandamme et al., 1996; Wayne et al., 1987), the results of DNA-DNA hybridization and physiological and biochemical tests allowed the genotypic and phenotypic differentiation of strain G-soil-2-3 ${ }^{\mathrm{T}}$ from the phylogenetically most closely related Paenibacillus species.

Strain G-soil-2-3 $3^{\mathrm{T}}$ was isolated on Luria-Bertani agar (USB Corporation) from a sample of farmland soil from Taiwan. Paenibacillus assamensis JCM $13186^{\mathrm{T}}$, Paenibacillus alvei IAM $1258^{\mathrm{T}}$ and Paenibacillus apiarius NRRL B-23460 ${ }^{\mathrm{T}}$ were received from culture collections. All strains were reactivated on trypticase soy agar (Difco) and checked for purity on nutrient agar (NA; Difco) after cultivation at $30{ }^{\circ} \mathrm{C}$ for 24-48 h. Strains were preserved at $-80^{\circ} \mathrm{C}$ in trypticase soy broth or by lyophilization.

Genomic DNA was extracted and purified by using the Qiagen Blood \& Cell Culture DNA kit. 16S rRNA genes were amplified by PCR and sequenced by using the MicroSeq Full 
Gene 16S rDNA Bacterial Sequence kit (PE Applied Biosystems). Sequencing was performed with an Applied Biosystems 310 DNA sequencer. Sequence assembly was performed by using the ABI PRISM DNA Sequencing Analysis software (PE Applied Biosystems) and phylogenetic analyses were performed via CLUSTAL X (Thompson et al., 1997) for alignment and MEGA version 3.1 (Kumar et al., 2004) for the neighbour-joining analysis. The $16 \mathrm{~S}$ rRNA gene sequence of strain G-soil-2-3 ${ }^{\mathrm{T}}$ was aligned with those of Paenibacillus species retrieved from the NCBI database. Sequences of Thermobacillus xylanilyticus CNCM I-1017 ${ }^{\mathrm{T}}$ and Bacillus subtilis subsp. subtilis DSM $10^{\mathrm{T}}$ were also included in the phylogenetic analysis for comparative purposes. Phylogenetic trees were constructed by using the neighbour-joining (Saitou \& Nei, 1987) and maximumparsimony (Fitch, 1971) methods. Confidence values of branches on the neighbour-joining tree were determined by performing a bootstrap analysis with 1000 replicates.

DNA G $+\mathrm{C}$ content and levels of DNA-DNA relatedness were determined with genomic DNA prepared by using a commercial kit (Genomic-tips; Qiagen). The G $+\mathrm{C}$ content was determined via reversed-phase HPLC according to Tamaoka \& Komagata (1984) with slight modifications. Nucleotides were separated by using a Cosmosil $5 \mathrm{C}_{18}$ column $(4.0 \times 150 \mathrm{~mm})$ (Waters) in a mobile phase composed of $0.2 \mathrm{M} \mathrm{NH}_{4} \mathrm{H}_{2} \mathrm{PO}_{4}$ /acetonitrile $(20: 1, \mathrm{v} / \mathrm{v})$ at a flow rate of $1 \mathrm{ml} \mathrm{min}^{-1}$ at room temperature. Nucleotides were detected and quantified by absorption at $260 \mathrm{~nm}$. DNA-DNA relatedness values between the novel strain and the type strains of recognized Paenibacillus species were determined by using the fluorometric hybridization method in microdilution wells (Ezaki et al., 1989; Tai et al., 2006). The fluorescence intensity of each well was measured with a Fluoroskan II microplate fluorometer (Labsystems) at a wavelength of $360 \mathrm{~nm}$ for excitation and at $450 \mathrm{~nm}$ for emission. Hybridization temperature was $45^{\circ} \mathrm{C}$.
The fatty acid composition was determined with the Sherlock Microbial Identification System (MIDI Inc.) as described by Chern et al. (2004). Extracts of the methylated fatty acids were prepared according to the protocol provided by the manufacturer and analysed with an Agilent $6890 \mathrm{~N}$ gas chromatograph equipped with a flame-ionization detector and 7683 Automatic Liquid Sampler. Identification of the peaks was made by comparing the results with the built-in TSBA 50 database (MIDI Inc.).

Respiratory quinones of the novel bacterium were identified according to Collins \& Jones (1981) and Komagata \& Suzuki (1987). The TLC-purified quinones were analysed with a Nova-Pak $\mathrm{C}_{18}(15 \times 3.9 \mathrm{~cm})$ column (Waters). Peaks were detected at $270 \mathrm{~nm}$ after elution with methanol/2-propanol $(2: 1)$ at a flow rate of $1 \mathrm{ml} \mathrm{min}{ }^{-1}$.

All phenotypic tests were performed on bacteria grown on $\mathrm{NA}$ at $30^{\circ} \mathrm{C}$ unless otherwise specified. General cell morphology was studied by using phase-contrast microscopy (Eclipse E600; Nikon). The Gram reaction was performed with a four-step Gram stain kit (Becton Dickinson) according to the manufacturer's instructions. Catalase activity, oxidase activity and oxidation-fermentation reactions were determined by using standard methods (Barrow \& Feltham, 1993). Hydrolysis of starch and casein were determined as described by Cowan \& Steel (1974). The silver-plating method was applied to stain the flagella (West et al., 1977). Additional physiological and biochemical tests were performed with the API 50CHB and API 20E systems (bioMérieux) according to the manufacturer's instructions.

$16 \mathrm{~S}$ rRNA gene sequence analysis indicated that strain Gsoil-2-3 ${ }^{\mathrm{T}}$ belongs within the genus Paenibacillus (Fig. 1). The levels of sequence similarity of $95.0-95.7 \%$ between strain G-soil-2-3 $3^{T}$ and the type strains of the phylogenetically most closely related species, $P$. assamensis, $P$. alvei and $P$. apiarius seem to exclude a possible relationship at the

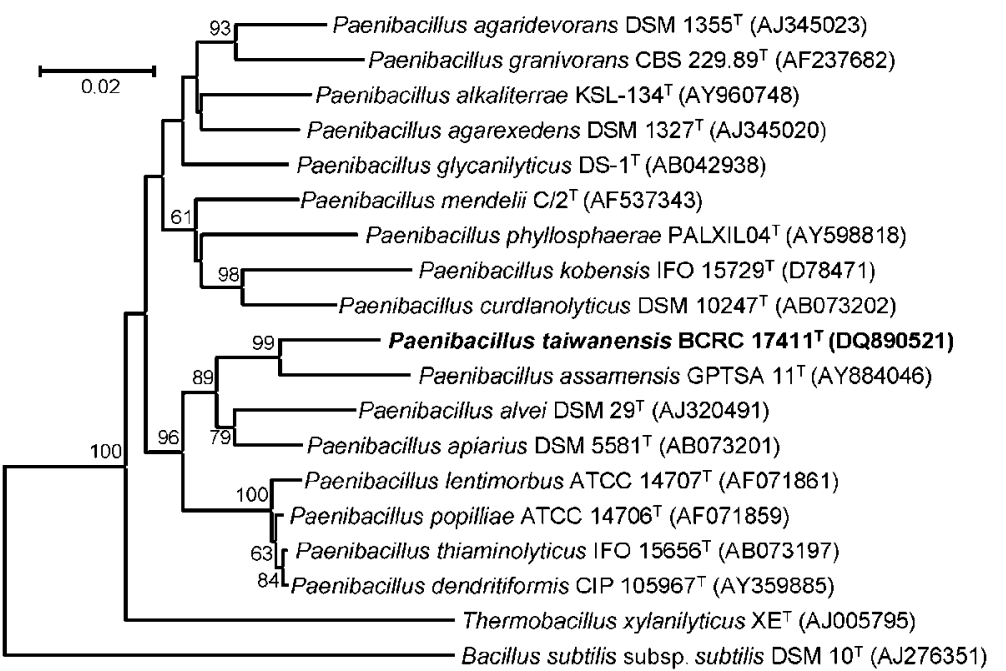

Fig. 1. Neighbour-joining phylogenetic tree, based on 16S rRNA gene sequences, showing the relationships among Paenibacillus species. Database accession numbers for the sequences used in the analysis are given in parentheses. Bootstrap percentages (based on 1000 replicates) are given at branching points. Thermobacillus xylanilyticus $\mathrm{XE}^{\top}$ and Bacillus subtilis subsp. subtilis DSM $10^{\top}$ were used as the outgroup to root the tree. Bar, $2 \%$ nucleotide substitution rate. 
species level with one of these taxa (Stackebrandt \& Goebel, 1994; Vandamme et al., 1996; Hagström et al., 2000), and DNA-DNA relatedness values between strain G-soil-2-3 ${ }^{\mathrm{T}}$ and strains $P$. assamensis BCRC $17411^{\mathrm{T}}, P$. alvei DSM $29^{\mathrm{T}}$ and P. apiarius DSM $5581^{\mathrm{T}}$ were only $2.8-9.0 \%$. Therefore, the new isolate is considered to represent a novel species of the genus Paenibacillus.

The fatty acid profiles of strain G-soil-2-3 ${ }^{\mathrm{T}}$ and related taxa are presented in Table 1. Only minor differences were noted between strain G-soil-2-3 ${ }^{\mathrm{T}}$ and other Paenibacillus species. The dominant fatty acids for all strains investigated (mean level above $10 \%)$ were anteiso- $\mathrm{C}_{15: 0}(40.5 \%)$, iso- $\mathrm{C}_{15: 0}$ $(13.1 \%)$ and iso- $\mathrm{C}_{16: 0}(10.8 \%)$ (Table 1). Strain G-soil-2$3^{\mathrm{T}}$ contained menaquinone MK-7 as the predominant isoprenoid quinone (97.1\%); this is in accordance with all other members of the genus Paenibacillus.

Phenotypic features that distinguish the novel species from phylogenetically related Paenibacillus species are listed in Table 2 and in the species description below.

\section{Description of Paenibacillus taiwanensis sp. nov.}

Paenibacillus taiwanensis (tai.wan.en'sis. N.L. masc. adj. taiwanensis of Taiwan, where the type strain was isolated).

Table 1. Cellular fatty acid compositions of strain G-soil-2$3^{T}$ and type strains of selected Paenibacillus species

Strains: 1, strain G-soil-2-3 $3^{\mathrm{T}} ; 2$, P. assamensis GPTSA $11^{\mathrm{T}}$ (data from Saha et al., 2005); 3, P. apiarius MTCC $1497^{\mathrm{T}}$ (Saha et al., 2005); 4, P. alvei IFO $3343^{\mathrm{T}}$ (Shida et al., 1997a). Values are percentages of total fatty acids. ND, Not detected; NM, not mentioned; tr, trace $(<1 \%)$.

\begin{tabular}{|c|c|c|c|c|}
\hline Fatty acid & 1 & 2 & 3 & 4 \\
\hline iso- $\mathrm{C}_{14: 0}$ & 2.47 & 4.74 & $\operatorname{tr}$ & $\operatorname{tr}$ \\
\hline $\mathrm{C}_{14: 0}$ & 2.42 & 1.80 & 1.15 & 2.3 \\
\hline iso- $\mathrm{C}_{15: 0}$ & 13.08 & 6.03 & 13.55 & 12.3 \\
\hline $\mathrm{C}_{15: 0}$ & $\mathrm{ND}$ & ND & ND & 1.6 \\
\hline anteiso- $\mathrm{C}_{15: 0}$ & 40.47 & 48.42 & 49.96 & 53.9 \\
\hline $\mathrm{C}_{16: 1} \omega 7 c$ alcohol & 1.59 & 5.01 & ND & NM \\
\hline iso- $\mathrm{C}_{16: 0}$ & 10.78 & 11.59 & 6.52 & 2.3 \\
\hline $\mathrm{C}_{16: 1} \omega 11 c$ & 4.25 & 6.16 & 2.18 & $1.3^{\star}$ \\
\hline $\mathrm{C}_{16: 0}$ & 6.16 & 3.49 & 5.9 & 15.3 \\
\hline iso- $\mathrm{C}_{17: 1} \omega 10 c$ & 2.75 & 1.18 & 1.35 & $\operatorname{tr}^{\star}$ \\
\hline iso- $\mathrm{C}_{17: 0}$ & 6.13 & 1.59 & 6.39 & 3.3 \\
\hline anteiso- $\mathrm{C}_{17: 0}$ & 7.30 & 5.68 & 8.80 & 3.3 \\
\hline $\mathrm{C}_{17: 0}$ & $\operatorname{tr}$ & 1.56 & 1.25 & NM \\
\hline Summed feature $4 \dagger$ & 1.42 & 1.64 & $\operatorname{tr}$ & NM \\
\hline
\end{tabular}

${ }^{*}$ The cis/trans isomeric nature of the fatty acid was not specified. $\dagger$ Fatty acids that could not be separated by GC with the Microbial Identification System (Microbial ID) software were considered summed features. Summed feature 4 comprises iso- $\mathrm{C}_{17: 1} \mathrm{I}$ and/or anteiso- $\mathrm{C}_{17: 1} \mathrm{~B}$.
Cells are rod-shaped $(2.5-6.8 \times 0.7-0.9 \mu \mathrm{m})$, Gram-variable, facultatively anaerobic, mesophilic, capable of forming endospores and motile by means of peritrichous flagella. Colonies are flat with undulate margins and greyish white on NA. Grows at $10-45^{\circ} \mathrm{C}$ (optimum $30^{\circ} \mathrm{C}$ ) on NA. Unable to grow below $5{ }^{\circ} \mathrm{C}$ or above $50^{\circ} \mathrm{C}$. The $\mathrm{pH}$ range for growth is 4.5-12 (optimum pH 6-8). Grows on NA containing $4 \%$ $\mathrm{NaCl}(\mathrm{w} / \mathrm{v})$. Positive for catalase and $\beta$-galactosidase but negative for oxidase, urease, arginine dihydrolase, lysine decarboxylase, ornithine decarboxylase, tryptophan deaminase and gelatinase (API 20E). Indole, $\mathrm{H}_{2} \mathrm{~S}$ and acetoin are not produced. Hydrolyses starch and casein. Produces acid from ribose, D-glucose, glycerol, methyl $\alpha$-D-glucoside, $N$ acetylglucosamine, amygdalin, aesculin, D-cellobiose, Dmaltose, sucrose, D-trehalose, D-melezitose, gentiobiose, D-turanose and gluconate. No acid is produced from any other substrate in the API $50 \mathrm{CH}$ system. The major fatty acids are anteiso- $\mathrm{C}_{15: 0}(40.5 \%)$, iso- $\mathrm{C}_{15: 0}(13.1 \%)$, iso$\mathrm{C}_{16: 0}(10.8 \%)$, anteiso- $\mathrm{C}_{17: 0}(7.3 \%), \mathrm{C}_{16: 0}(6.2 \%)$ and iso$\mathrm{C}_{17: 0}(6.2 \%)$. The predominant menaquinone is MK-7

Table 2. Differential phenotypic characteristics of strain Gsoil-2-3 $3^{\top}$ and type strains of phylogenetically related Paenibacillus species

Strains: 1 , strain G-soil-2- $3^{\mathrm{T}} ; 2, P$. assamensis GPTSA $11^{\mathrm{T}} ; 3, P$. apiarius BCRC $17384^{\mathrm{T}}$; 4, P. alvei BCRC $11220^{\mathrm{T}}$. Data for $P$. assamensis GPTSA $11^{\mathrm{T}}$ were taken from Saha et al. (2005); the remaining data were from this study. + , Positive; - , negative.

\begin{tabular}{|c|c|c|c|c|}
\hline Characteristic & 1 & 2 & 3 & 4 \\
\hline \multicolumn{5}{|l|}{ Growth at: } \\
\hline $10{ }^{\circ} \mathrm{C}$ & + & - & - & - \\
\hline $45^{\circ} \mathrm{C}$ & + & - & - & + \\
\hline $\mathrm{pH} 4.5$ & + & - & + & - \\
\hline Production of indole & - & - & - & + \\
\hline \multicolumn{5}{|l|}{ Acid production from: } \\
\hline Glycerol & + & + & + & - \\
\hline Adonitol & - & - & - & + \\
\hline D-Galactose & - & - & + & - \\
\hline D-Mannose & - & + & - & - \\
\hline Inositol & - & - & + & - \\
\hline Methyl $\alpha$-D-glucoside & - & + & + & - \\
\hline Amygdalin & + & - & + & - \\
\hline Arbutin & - & - & + & + \\
\hline Salicin & + & - & + & - \\
\hline D-Cellobiose & + & - & + & - \\
\hline D-Melibiose & - & + & + & + \\
\hline Sucrose & + & - & + & - \\
\hline D-Trehalose & + & - & + & - \\
\hline D-Melezitose & + & - & + & - \\
\hline D-Raffinose & - & - & + & + \\
\hline Starch & - & + & + & + \\
\hline Glycogen & - & + & + & - \\
\hline Gluconate & + & - & + & - \\
\hline
\end{tabular}


(97.1\%). The DNA G + C content is $44.6 \mathrm{~mol} \%$. The species is phylogenetically most closely related to P. assamensis.

The type strain, G-soil-2-3 ${ }^{\mathrm{T}} \quad\left(=\mathrm{BCRC} \quad 17411^{\mathrm{T}}=\mathrm{IAM}\right.$ $\left.15414^{\mathrm{T}}=\mathrm{LMG} 23799^{\mathrm{T}}=\mathrm{DSM} 18679^{\mathrm{T}}\right)$, was isolated in 2000 from farmland soil in Wu-Feng, Taiwan.

\section{Acknowledgements}

We thank H. K. Chen for his technical assistance. Special thanks go to T. Y. Liu, C. C. Liao and G. F. Yuan (Food Industry Research and Development Institute, Taiwan) for their encouragement. This research was supported by the Taiwanese Ministry of Economic Affairs (project no. 95-EC-17-A-17-R7-0525).

\section{References}

Ash, C., Farrow, A. E., Wallbanks, S. \& Collins, M. D. (1991). Phylogenetic heterogeneity of the genus Bacillus revealed by comparative analysis of small-subunit-ribosomal RNA sequences. Lett Appl Microbiol 13, 202-206.

Ash, C., Priest, F. G. \& Collins, M. D. (1993). Molecular identification of rRNA group 3 bacilli (Ash, Farrow, Wallbanks and Collins) using a PCR probe test. Proposal for the creation of a new genus Paenibacillus. Antonie van Leeuwenhoek 64, 253-260.

Barrow, G. I. \& Feltham, R. K. A. (1993). Cowan and Steel's Manual for the Identification of Medical Bacteria, 3rd edn. Cambridge: Cambridge University Press.

Chern, L.-L., Stackebrandt, E., Lee, S.-F., Lee, F.-L., Chen, J.-K. \& Fu, H.-M. (2004). Chitinibacter tainanensis gen. nov., sp. nov., a chitindegrading aerobe from soil in Taiwan. Int J Syst Evol Microbiol 54, 1387-1391.

Collins, M. D. \& Jones, D. (1981). A note on the separation of natural mixtures of bacterial ubiquinones using reverse-phase partition thinlayer chromatography and high performance liquid chromatography. J Appl Bacteriol 51, 129-134.

Cowan, S. T. \& Steel, K. J. (1974). Manual for the Identification of Medical Bacteria. London: Cambridge University Press.

Ezaki, T., Hashimoto, Y. \& Yabuuchi, E. (1989). Fluorometric deoxyribonucleic acid-deoxyribonucleic acid hybridization in microdilution wells as an alternative to membrane filter hybridization in which radioisotopes are used to determine genetic relatedness among bacterial strains. Int J Syst Bacteriol 39, 224-229.

Fitch, W. M. (1971). Toward defining the course of evolution: minimum change for a specific tree topology. Syst Zool 20, 406-416.

Garrity, G. M. \& Holt, J. G. (2001). Taxonomic outline of the Archaea and Bacteria. In Bergey's Manual of Systematic Bacteriology, 2nd edn, vol. 1, The Archaea and the Deeply Branching and Phototrophic Bacteria, pp. 155-166. Edited by D. R. Boone, R. W. Castenholz \& G. M. Garrity. New York: Springer.

Hagström, Å., Pinhassi, J. \& Zweifel, U. L. (2000). Biogeographical diversity among marine bacterioplankton. Aquat Microb Ecol21,231-244.
Kämpfer, P., Buczolits, S., Albrecht, A., Busse, H.-J. \& Stackebrandt, E. (2003). Towards a standardized format for the description of a novel species (of an established genus): Ochrobactrum gallinifaecis sp. nov. Int J Syst Evol Microbiol 53, 893-896.

Komagata, K. \& Suzuki, K. (1987). Lipid and cell wall analysis in bacterial systematics. Methods Microbiol 19, 161-207.

Kumar, S., Tamura, K. \& Nei, M. (2004). MEGA3: integrated software for molecular evolutionary genetics analysis and sequence alignment. Brief Bioinform 5, 150-163.

Saha, P., Mondal, A. K., Mayilraj, S., Krishnamurthi, S., Bhattacharya, A. \& Chakrabarti, T. (2005). Paenibacillus assamensis sp. nov., a novel bacterium isolated from a warm spring in Assam, India. Int J Syst Evol Microbiol 55, 2577-2581.

Saitou, N. \& Nei, M. (1987). The neighbor-joining method: a new method for reconstructing phylogenetic trees. Mol Biol Evol 4, 406-425.

Shida, O., Takagi, H., Kadowaki, K. \& Komagata, K. (1996). Proposal for two new genera, Brevibacillus gen. nov. and Aneurinibacillus gen. nov. Int J Syst Bacteriol 46, 939-946.

Shida, O., Takagi, H., Kadowaki, K., Nakamura, L. K. \& Komagata, K. (1997a). Transfer of Bacillus alginolyticus, Bacillus chondroitinus, Bacillus curdlanolyticus, Bacillus glucanolyticus, Bacillus kobensis, and Bacillus thiaminolyticus to the genus Paenibacillus and emended description of the genus Paenibacillus. Int J Syst Bacteriol 47, 289-298.

Shida, O., Takagi, H., Kadowaki, K., Nakamura, L. K. \& Komagata, K. (1997b). Emended description of Paenibacillus amylolyticus and description of Paenibacillus illinoisensis sp. nov. and Paenibacillus chibensis sp. nov. Int J Syst Bacteriol 47, 299-306.

Stackebrandt, E. \& Goebel, B. M. (1994). Taxonomic note: a place for DNA-DNA reassociation and 16S rRNA sequence analysis in the present species identification in bacteriology. Int J Syst Bacteriol 44, 846-849.

Tai, C.-J., Kuo, H.-P., Lee, F.-L., Chen, H.-K., Yokata, A. \& Lo, C.-C. (2006). Chryseobacterium taiwanense sp. nov., isolated from soil in Taiwan. Int J Syst Evol Microbiol 56, 1771-1776.

Tamaoka, J. \& Komagata, K. (1984). Determination of DNA base composition by reversed-phase high-performance liquid chromatography. FEMS Microbiol Lett 25, 125-128.

Thompson, J. D., Gibson, T. J., Plewniak, F., Jeanmougin, F. \& Higgins, D. G. (1997). The CLUSTAL_X windows interface: flexible strategies for multiple sequence alignment aided by quality analysis tools. Nucleic Acids Res 25, 4876-4882.

Vandamme, P., Pot, B., Gillis, M., de Vos, P., Kersters, K. \& Swings, J. (1996). Polyphasic taxonomy, a consensus approach to bacterial systematics. Microbiol Rev 60, 407-438.

Wayne, L. G., Brenner, D. J., Colwell, R. R., Grimont, P. A. D., Kandler, O., Krichevsky, M. I., Moore, L. H., Moore, W. E. C., Murray, R. G. E. \& other authors (1987). International Committee on Systematic Bacteriology. Report of the ad hoc committee on reconciliation of approaches to bacterial systematics. Int J Syst Bacteriol 37, 463-464.

West, M., Burdash, N. M. \& Freimuth, F. (1977). Simplified silverplating stain for flagella. J Clin Microbiol 6, 414-419. 